\title{
Strata and Strategies of Teaching About the Global "Other” Using Critical Feminist Pedagogical Praxis
}

\author{
ABSTRACT \\ In this article, I analyze the way "globalization" is deployed in US universities as a value \\ addition. I explore issues of teaching about the global "Other," the "third world," and other \\ unfamiliar, objectified spaces. Through critical discourse analysis of syllabi, I outline some \\ representational and pedagogical trends. I also draw from my experience of teaching \\ undergraduate-level globalization-focused courses, including courses on transnational \\ feminisms, international literature, social movements, migrations, and socioeconomic \\ exchanges. Teaching about "the other" often leads to a multiplier effect of othering within the \\ classroom. Using transnational feminist perspectives, I argue that teaching such classes on \\ "global," "transnational," or "international" women, gender, sexuality, and feminisms requires \\ decentering not just of dominant paradigms but also of oneself as purveyor of insider or \\ global knowledge. I also argue, as have many others before me, that a classroom can serve as a \\ site for epistemic injustices and colonizing acts; we must attempt to find ways in which such \\ neocolonial damages can be mitigated. This article is an exercise in finding some ways to \\ decenter and decolonize dominant discourses on the global Other and suggest critical and \\ compassionate pedagogical strategies.
}

\section{KEYWORDS}

pedagogy, epistemology, globalization, colonization, syllabus analysis

\section{STRATA AND STRATEGIES OF TEACHING ABOUT THE GLOBAL "OTHER" USING CRITICAL FEMINIST PEDAGOGICAL PRAXIS}

\begin{abstract}
Political action on the side of the oppressed must be pedagogical action in the authentic sense of the word, and, therefore, action with the oppressed. Those who work for liberation must not take advantage of the emotional dependence of the oppressed - dependence that is the fruit of the concrete situation of domination which surrounds them and which engendered their unauthentic view of the world. Using their dependence to create still greater dependence is an oppressor tactic.
\end{abstract}

-Paulo Freire (2005, p. 66)

What is the best way to teach about why Facebook allows users to overlay their profile picture with France's flag after a terrorist attack in Paris but not Nigeria's or Pakistan's when horrifying attacks kill school and college students in Peshawar and Garissa? How do we explain why, after an attack on a Quebec City mosque or the recent Mogadishu explosions, there was no collective expression of grief and shock on social media (in the manner of "Je suis Charlie")? How do we persuasively explain to our 
students why certain acts are labeled terrorist and others not-based on the terrorist's visible identity? How do we re-historicize re/current events that serve to reinforce xenophobia, ethnocentrism, and other forms of deep distrust of the "other'? With the rapid internationalization of scope and focus of university undertakings in the United States, we need to rethink the meaning of globalization and what it means to teach about the Other, to discuss the "there" versus "here" and "them" versus "us/US".

In this article I explore issues of teaching topics focused on the global Other in the US undergraduate context: the Other as opposed to Self, to the familiar, local, understandable, or properly translatable. I use critical discourse analysis to understand how the Other is represented in course curricula that promise or fulfill global intercultural competence. I follow that by offering some pedagogical strategies drawn from my own classroom practices using insights from transnational feminisms and varied forms of critical pedagogy - two overlapping corpus of decolonizing praxis that challenge us to rethink colonial and colonizing categories, identities, and ideologies.

The Other exemplifies such a category. Other can also mean an "outsider within" or "stranger" status that is located outside the schema of accepted, default statuses-often that of white cis-male insiders holding power and privilege in the United States and globally (Collins, 1986). The other thus is the state or status of the colonized, the marginalized, the objectified, the silenced, and the dehumanized. Spivak (1988) further explains that "[o]utside (though not completely so) the circuit of international division of labor, there are people whose consciousness we cannot grasp if we close off our benevolence by constructing a homogeneous Other referring only to our own place in the seat of the Same or the Self" (p. 288). Examples of such homogeneity are the identity categories of "Muslims," "Africans," and, as Chandra T. Mohanty (1988) so eloquently argues, the "third world woman." These identities grippingly capture Western imagination, contribute to Western nationalisms, and create global subjects to be studied, interrogated, helped, and often pitied in US academic and nonprofit spaces.

I draw from existing discourse on globalization and postsecondary education-after all, widespread teaching about the Other is a direct consequence of internationalization and globalization of US universities - and critical discourse analysis of college curricula that focus on "other people" and "other cultures," often placing women and gender issues at the crux of the inquiry. I analyze 50 undergraduate syllabi from 30 universities that have an "international requirement" in place. I also reflect on my own experience of teaching such courses through a lens of feminist pedagogy that embraces critical thinking and justice within and without classrooms. This often involves challenging my own and students' deeply entrenched worldviews and challenging the rapidly corporatizing culture of the academia.

Jespersen (2014) states of transformative feminist praxis: “The project of social justice in education, or maybe any education, involves ideological shifts. These shifts include profound changes to the self. Anger, unease, guilt, and grief are all to be expected given that we ask our students, on a daily basis, to rethink normative beliefs. One way that ideological beliefs change is through a process of identification, which occurs on conscious and unconscious levels. As we build our identities through identification, the incorporation of the same and other into ourselves, we also modify ideological makeup" (p. 221). Scholars such as Alexander and Mohanty (2010) believe that curricular analysis paves a way to understanding hierarchies of place and space. "If to talk about space is to talk about geography, then to talk about geography is also to talk about land and the fierce contestation over lands that are at the center of both neoimperial and colonial land appropriation" (p. 39). They also ask "in what ways do 
syllabi bend or reinforce normative cartographic rules?” (p. 31). My analysis of syllabi reveals a trend of symbolic appropriation and ideological colonization, and sometimes illogical blanket assertions about the global Other.

\section{BACKGROUND AND CONTEXT}

Analysis of syllabi can reveal much about the ethical and methodological nature of curricular development, a line of inquiry in the field of Scholarship of Teaching and Learning (SoTL). Felten (2013) lists some principles guiding good practice in such scholarship : the inquiry is focused on student learning; grounded in context; methodologically sound; conducted in partnership with students, and appropriately public: "Taken together, these five principles can be used as guideposts for developing and refining both individual SoTL inquiries and larger SoTL initiatives" (p. 124). My aim in this article is to provide feminist and anticolonial context and critique. The questions I address pertain to teaching and learning under the current trend of globalizing and internationalizing curricula in US universities that will have an impact on students as citizens, workers, and members of society in their varied personal and collective roles. While this is not a study of that impact, I aim at interrogating what and how students learn about the Other and how the binaries of local and global self and Other are positioned in the syllabus, which is not merely an informational document but also functions in the nature of a contract between student and faculty and, indeed, between student and the educational institution.

My purpose in this article also is to suggest some pedagogical practices that will help teach globalization and the global Other without abandoning a critical edge. Transnational feminist methodology provides that critical edge - an explicitly antiracist, anticapitalist, and anticolonial methodology that studies issues of gendered identities, representation, citizenship, immigration, social movements, production, and consumption in a globalizing world.

\section{International, global, multicultural, and intercultural requirements}

Courses that fulfill international or multicultural requirements are currently popular and widespread in US universities. Most of these courses aim to impart knowledge about the contemporary globalized world-looking outward at the world from the perspective of US politics, economics, and society or culture. This gaze is often anthropological, and it follows the neoliberal logic of the world being the oyster of culture-curious and capitalist-entrepreneurial US citizens. The United States is usually accorded a neutral-benevolent position in this discussion on globalization-a position of objectivity, often a position of umpiring, assessing, and problem solving. "International requirement" is sometimes explained simply as "course work containing international content," as is the case for the Darla Moore School of Business of the University of South Carolina School of Business (n.d.), or described in a more detailed manner, such as the following from University of Utah, where I have taught courses that satisfy the international requirement:

The upper-division international requirement will give students a broad base of knowledge about global issues and perspectives in a comparative context by exploring big questions both contemporary and enduring. It will introduce students to international frames of reference so that they may think critically about long-standing and newly emerging international issues. These courses will help students accept and appreciate the interdependence of nations and the viewpoints of other nations and give 
them the ability to communicate with people across international borders. (Office of Undergraduate Education, University of Utah, 2019)

These goals seem important to prepare students for a globalizing world as citizens and workers who can benefit from open borders and mitigate the disadvantages of closing borders-also a characteristic of globalization. In this process, however, US universities often present themselves officially as bearer of exceptional analytical insight ready to understand the complexities of a global society, but issues of US exceptionalism are rarely brought up (Ong, 2006). Is the study of globalization really allowing students to understand global politics and processes better? Or are these courses deepening the binaries of us/them, first world/third world, developed/developing? Do they represent collectively "pedagogy of the oppressor" in an age when the notion of institutional oppression allows us to be comfortable in our individual forts of meritocracy, consumption, and complicity? How do we teach about globalization and the Other in a way that provides a clear understanding of United States' position in the globe instead of treating globalization as a story and history of poverty, catastrophe, terrorism, and indignity of non-US "others"? That is, when we are not teaching globalization as a success story that brings cellphones to the poor in India and Hollywood movies to youth in Nigeria? How do we teach globalization to students who have very little exposure to regional, let alone national or international, issues? This article is not an argument against teaching such courses that are identified as being about global gender issues, international literature, world religion, world culture, or even world human geography - courses whose titles contain words such as transnational, international, global, or the world. Instead, it is an invitation to critically think about these courses - their purpose and pedagogy, as well as their connection to the university's overall internationalizing mission.

\section{CRITICAL DISCOURSE ANALYSIS OF SYLLABI}

I used critical discourse analysis on randomly picked undergraduate course syllabi from 2010 through 2017 that satisfy global or international requirements. For an earlier research project, I had sampled 50 statements on "international," "global," or "intercultural" requirements from large, four-year, public universities in the United States (identified as such by Carnegie classification). For this research project, I went to online repositories of syllabi of sociology and gender, women's, or sexuality studies courses hosted by 30 randomly picked universities from the 50. All syllabi were accessed online through repositories maintained by universities, including those in syllabus libraries and posted by instructors, and through syllabus repositories such as the Teaching Resources and Innovations Library for Sociology, or TRAILS, hosted by the American Sociological Association.

I identified more than 100 syllabi that satisfied an international or global requirement as instituted by the university, assigned them numbers, and used a list randomizer to pick 50 syllabi. If the randomly picked syllabi did not contain course or learning objectives or course descriptions, I removed them from my sample and reused the randomizer to find replacements. All syllabi in the randomized sample are from US universities, and the universities are in all states except Alaska, Delaware, North Dakota, and Connecticut (not a purposeful but a chance omission).

The rationale for focusing on institutions with large undergraduate populations is to underscore the substantial number of students that take courses satisfying international, global, or intercultural requirements. However, excluding smaller undergraduate institutions, such as small liberal arts colleges, 
does not necessarily mean that these institutions do not require their students to take designated "international" courses; in fact, smaller or private institutions often require students to study abroad as a part of developing international awareness, cultural competence, and marketable skills (Doerr, 2016). For this project however, I focused on classroom teaching and how syllabi of courses fulfilling international requirements frame the notion of the "global" or "international."

Critical discourse analysis can help understand phenomena that are complexes of meanings, networks of interpretation, and constituted through practices. For my project, critical discourse analysis helped explain how subjects and studiers of globalization come together, arrange themselves under collective identities and exercise collective agency. "One crucial presupposition of adequate critical discourse analysis is understanding the nature of social power and dominance. Once we have such an insight, we may begin to formulate ideas about how discourse contributes to their reproduction... Social power is based on privileged access to socially valued resources, such as wealth, income, position, status, force, group membership, education or knowledge" (van Djik, 1993, p. 254).

My analysis was further informed by transnational feminist theory (see my discussion on critical edge earlier). Alexander and Mohanty (2010) aver: "What might a map of a radical, non-normative transnational feminist solidarity pedagogy that is attentive to genealogies and spatializations of power across multiple borders look like? Clearly syllabi are crucial spaces for thinking and reconfiguring knowledge, spatial practices and for respatializing power" (p. 41). This is a starting point for my inquiry into the courses that satisfy international requirements. I analyzed syllabi to understand three issues: (1) if and how globalization was defined and/or explained; (2) whether or not course objectives provided rationale for studying globalization, and (3) what identities and experiences were deemed central to the study of globalization as a phenomenon in the course. While I closely read each of the 50 syllabi, I found course descriptions, course objectives, learning outcomes, assignments, and readings assigned to be indicative of a particular course's treatment of globalization. I wanted to see, among other things, whether globalization is treated as a pervasive phenomenon that has an impact on all-this impact being a function of people's geopolitical and social location. I also wanted to understand whether and how globalization is presented in all its complexity, or as a composite of non-US people's experiences (positive, negative, or mixed) that deepens the us/them divide.

Critical discourse analysis focuses on text to reveal strata and structures of power and hierarchy, deeply tied to social identity categories such as race, gender, and class (van Djik, 1993). Additionally for my project, identities associated with location and language was particularly important. I used my research questions to analyze the discourse of or around globalization as articulated in syllabi. Critical discourse analysis also reveals the repetitive nature of textual formation that reproduces existing power structures through reinforcement or resistance, and this repetition became obvious as I started finding patterns in the text.

\section{FINDINGS OF CURRICULAR TRENDS IN TEACHING ABOUT THE OTHER}

Forty-four out of 50 syllabi contained a definition or explanation of what globalization is, and about half of them included colonization as a form of globalization-providing a sense that globalization is not a brand-new process. Only 19 out of 50 syllabi explained the purpose or rationale for focusing on globalization. Gender emerged as a central identity under scrutiny with "gender justice” or “women's rights" emerging as a topic of inquiry in 40 syllabi. 
Globalizing or "internationalizing" curricula is not a recent trend in US universities, but it has definitely kept up with the pace, scale, and deepening of globalization of recent times. Thus covering recent events in syllabi is understandable. However, recent events cannot be properly grasped in the absence of histories of colonization and neocolonialism brought on by economic liberalization in many countries in the global south. Fewer than 10 syllabi make note of these histories and realities in detail. The global development framework often takes an incomplete and altruistic approach to solving global problems by developing the "developing" spaces_ignoring the fact that development can be big business, and that the goals of development can be antithetical to the goals of human rights (Mies \& Bennholdt-Thomsen, 1999; Grewal, 2005; Hobart, 2002). This linear framework that privileges capitalist development and the Western notion of human rights is widely used in the way globalization is handled within US universities - 40 out of 50 syllabi emphasized economic and social development of "others" from a Western perspective. Table 1 summarizes the key findings from my analysis of syllabi.

Table 1: Analysis of syllabi that fulfill global, international, or intercultural requirements

\begin{tabular}{|l|c|}
\hline SYLLABI ELEMENTS & PRESENT IN NUMBER OF SYLLABI (N = 50) \\
\hline Definition and/or explanation of globalization & 44 \\
\hline Rationale for studying globalization & 19 \\
\hline Histories of colonization & 9 \\
\hline Global problems/issues as located outside the United States & 20 \\
\hline Colonization as a topic & 21 \\
\hline Gender as a topic & 40 \\
\hline Women's lives/problems as focus within gender as a topic & 34 \\
\hline Diversity as a topic & 29 \\
\hline
\end{tabular}

Close reading and analysis of syllabi also revealed the following trends: centrality of gender within courses on globalization; globalization as a context for diversity and the need for diversity rationalizes study of globalization; and the "globe" as a social observatory that exists outside the United States. Below, I discuss these trends and offer my reflections.

\section{Centrality of gender within globalization curricula}

Forty out of 50 syllabi focus on gender issues - which seems to translate to "women's issues." I noticed that 34 out of 40 syllabi that focus on gender issues make no mention of men's lives, different forms of masculinities, or the relational aspects of gender where categories of "male" and female" are cocreated by heteronormative, capitalist, and colonial cultures worldwide that embrace a strong gender dualism. The upsurge of interest of global gender issues or "third world women" can be located within a broader tendency - internationalization of US academe and its embracing of globalization as an exceptional educational as well as revenue-generation opportunity (Chowdhury, 2009; Moallem, 2006).

In the descriptive language of the syllabi, Other women inhabit three categories: (1) culturally oppressed, (2) culturally oppressed and defiantly resistant, and (3) culturally oppressed and hence persons of interest for the transnational civil society—as those serviced by nongovernmental organizations. The first group needs international (presumably US) attention and help; those belonging in the second group are helping themselves through creating local coalitions and alliances, art, and news. The third group constitutes clientele for policy advocacy. All three groups are current or potential 
beneficiaries or participants of global development brought about through development aid. Issues of female circumcision, acid attacks in South Asia, and other forms of gender violence are taught as global social problems. Women's labor movements and women's land rights movements coexist on the syllabi along with issues of biopiracy and democratic participation.

This form of topical treatment of women's issues within international education curricula is reminiscent of the transnational nongovernmental organizations' agendas of offering economic selfdetermination and market participation of women as cure for cultural oppression. According to Chowdhury (2011 p. 187), this agenda decontextualizes and objectifies oppression:

[Nongovernmental organizations] link rural women to globalization (as consumers and producers in the capitalist market), and they rapture some local-level power systems that exercise social and economic control over women. Certainly NGOs servings the poor are also constantly innovating in difficult circumstances with limited resources. Yet in the final analysis, development NGOs and donor organizations have barely engaged in anticolonial and anticlassist interrogations and continue to operate with the assumption that development and empowerment are about integrating poor women into the global economy and thereby reducing emphasis on issues of dignity and social justice.

Globalization and global-readiness is a sought-after commodity for students, some of whom nurse ambitions to work in non-US locations. Many assignments invite students to think critically about global gender problems and suggest solutions. Critical thinking involves understanding issues in context yet the same syllabi leave out lessons on colonialism and global capitalism. They train students to think like workers in nongovernmental organization with passports that allow easy access to global spaces.

This form of scrutinizing non-US women in classrooms and curricula also perpetuate "the regulative project of managing populations through regimes of welfare that produced women as key subjects for governance" (Grewal 2005, p. 134). It is also reminiscent of the way Mohanty $(1988 ; 2003)$ analyzes and criticizes the formation of a stereotypical "third world women" as a social and sociological category, often interpreted by white liberal feminists in terms of their "struggles." Another manifestation of this conceptual myopia is the liberal second wave feminist notion of the "universal woman" that erases the experiences of women of color within and without the United States. Thus, the notion of sisterhood and feminist solidarity are well critiqued (Ang, 1995; Desai, Bouchard, \& Detourney, 2010; Kaplan, 1994; Mohanty, 1988; 2003; Pfeil, 1994).

\section{Globalization as a hot topic and context for diversity}

As mentioned before, 19 syllabi explain the need for studying globalization. The "globe" is positioned as a diverse community and diversity as a frame of reference to understand local communities, just as the Other becomes a frame of reference to understand the self. Diversity as an institutional requirement necessitates teaching courses with a global focus within and without sociology and women's, gender, and sexuality studies. Globalization as global exchange of people, goods, and services that creates global communities and inequality is a historical process. Globalization, in the majority syllabi, emerges as the rapid pace and scale of social and economic changes at the planetary level that is new, current, and somewhat mystifying. It is a problem as well as a prospect, and "diversity" becomes a ubiquitous prospect and reality—albeit an apolitical one. 
The issue of teaching globalization in its manifold manifestations is something scholars within postcolonial studies, transnational feminist studies, and development studies have grappled with. They often agree that the neoliberal implications of the global empire and politics of knowledge creation are scarcely addressed in pedagogical practices within universities (Alexander \& Mohanty, 2010; Downing, 2014; McLaren, 2006). US public research universities hold a hegemonic and complicit position within exploitative global capitalism - their policies and positions aligned with supranational associations of governance and transnational corporations - that the university is implicated in "neocolonialism, multicultural commodity circulation, and the expansion of finance capital” (Chaput, 2008, p. 131). The way universities present globalization at the undergraduate level through a lens of global development and multiculturalism reflects this uncritical complicity. In most syllabi, the United States remains both the benevolent recommender and the repository for diversity.

In 15 out of the 19 syllabi that go beyond just mentioning globalization (see above), diversity is critically presented as connected to mass emigration as a result of US involvement in war and regional conflict (e.g., the influx of Vietnamese refugees to the United States in and after 1975). Many syllabi29 out of the original 50 - present diversity as a consequence of "humanitarian flows" that enriches a kind and generous US society by making it multicultural; course descriptions also imply looking at immigration that happened before the Nationality Act of 1940, whereby the United States was already a "nation of immigrants."

Diversity is also positioned as a demographic visibility. Only racial, national, and visible diversity seem to be important—not diversity of abilities, ideas, and social capital. "Diversity is only skin deep and profiled linguistically when the tools of a racist Eurocentrism are used to construct diversity and the dichotomy of multiculturalism institutionalizes the multiplicity of differences" (Lea, 2006, p. 221). Diversity thus becomes apolitical, reminiscent of individualized identity politics and micro-level gatekeeping within claims of global sisterhood that Mohanty $(1988 ; 2003)$ and others have critiqued. Just as "global women" cannot be an automatic basis of unity that creates sisterhood, "global citizen" is an interpretive code for passivity in the face of cultural imperialism.

How does this schema operate? How does diversity diversify and inclusion include as per institutional requirements? It seems that the "outsiders within" the institution, such as faculty and students of color, have to be familiar with the terms and conditions of diversity. In my own experience and that of others' this takes the form of well-meaning insider advice, ranging from changing an instructor's accent to mitigate the "oh no" effect to compliments about the absence of an accent. There is advice regarding professional development, including how to manage one's body, gestures, and overall impression. Scholars of color become "contained units," called upon to perform otherness within the academy (Minh-Ha, 1989; Mohanty, 2003). I myself have been asked several times to speak about the caste system, female feticide, and India's rape culture, and if anything I have said deviates from the expected and accepted story "on India," I have been reprimanded or not invited back.

Diversity becomes a mission by omission of differences, experiences, and histories. It is a localized missionary activity of creating a homogeneous community of passive, predictable subjects. Community is the product of work and of struggle; it cannot be created by a diversity decree or the positioning of the white US citizen as the normal, default subject position. 


\section{The globe as an observatory existing outside the United States}

Twenty out of the 40 syllabi that focused on gender issues looked at these issues outside of the United States. In my own field of gender studies and sociology of gender, there is a growing and healthy concern about studying "gender" through the lens of "development," gender as a site of transnational governmentality, and gender as a loose umbrella term for women's "issues" in a non-Western context. Gender is often central to the kind of student career empowerment that utilizes empowerment of thirdworld women, oppressed women, and immigrant women as a curricular trope. This trope is used in the kind of learning experiences that colleges and universities are supplying at the undergraduate level, learning experiences variedly known as "engaged learning," "high-impact learning," or "service-learning." The desire to help others or help the humanity often takes the form of helping women. This necessitates the category of a "third-world woman" who is perpetually underdeveloped, afflicted with oppressive traditions (often connected to religious beliefs), high illiteracy, and no individual free will to progress beyond the tenets of an oppressive collective that she herself inhabits (Mohanty, 1988).

Years ago, when I studied sociology as a graduate student, we would employ terms such as ethnocentrism, cultural superiority, imperialism, and anthropologization to explain this mindset. Yet those terms seem to contradict a rhetorical environment of cultural relativism and critical self-reflexivity that is a requirement for assignments on globalization. The US undergraduate classroom often is the first point of contact with the "international" or "transnational" focus on gender issues for hundreds and thousands of gender or women's studies students every semester-as well as others taking courses that satisfy international or diversity requirements. Many women's and gender studies courses fulfil these requirements, as do courses in anthropology, history, geography, world religions, peace and justice studies, and international relations. The disciplinary focus of these fields not only presents the potential for critical thinking, but it is also an opportunity to learn about unfamiliar identities, cultures, and experiences. Yet it seems that the majority of syllabi I analyzed deploy colonizing narrative where "the primary Euro-American narrative of the syllabus remains untouched, and examples from non-Western or Third World/South cultures are used to supplement and 'add' to this narrative" (Mohanty, 2003, p. 239).

I have taught some courses in women's and gender studies in several institutions that align with the university's internationalizing mission. While I definitely see value in teaching and learning global issues, I am painfully aware of how they create spaces of nationalist hegemony-fueled by patriotism, privilege, and liberal feminist feel-good. Most of my randomly picked 50 undergraduate syllabi with the terms global, international, or transnational in the course's title and that satisfied related requirements for this study reveal this tendency as well. While the syllabus alone does not reveal everything about the actual classroom interactions surrounding the issue of globalization, it can be a good indicator of the selective issues picked and approaches used for studying topics as varied as religion, poverty, microcredit, female genital cutting, human trafficking, and social movements. Oppression, underdevelopment, and violence are leitmotifs but rarely ever histories of resistance, (de)colonization, or heterogeneity of experiences. Women and gender studies syllabi fare better in understanding globalization and gender critically, but even then, in my own classes, I often encounter students who are puzzled by why our study of "global women" or "global gender" does not focus on foot binding, bride burning, and genital cutting. Sometimes students do not understand why their desire of "adopting a 
bunch of refugee babies," or sending "all my used shoes/clothes to refugees" is well meaning but not very helpful—offensive, in fact.

\section{PEDAGOGICAL STRATEGIES IN ERA OF INTERNATIONAL AS “REQUIREMENT”}

I have argued that teaching about the global Other often leads to a multiplier effect of "othering" within the classroom - especially when the university is located in a less-diverse community, often socially conservative. I also argue that it is possible to mitigate some of the othering happening on syllabi-setting the tone and expectation for a course. In this section, I lay out pedagogical strategies that I have found useful - while acknowledging that teaching is a two-way process of mutual learning. I acknowledge all the students I have taught over the years that tried hard to de-learn dominant discourses, pushed through their discomfort and defensiveness, taught me new information, and challenged me to do better.

Teaching is not is not merely about gathering and regurgitating knowledge. It is dialogic, and deeply political. Paulo Freire stated in his Pedagogy of the oppressed that "the dialogical theory of action does not involve a Subject, who dominates by virtue of conquest, and a dominated object. Instead, there are Subjects who meet to name the world in order to transform it" (Freire, 2005, p. 167). I treat my class meetings as opportunities to name the world, to question the order of things, to ground ourselves before we aspire to any form of global citizenship. To that end, the following are some strategies I use to address recurrent issues of studying globalization and global gender, in my syllabi and within the classrooms my students and I inhabit.

\section{Where is the "globe"?}

There is widespread confusion about space, scale, and geography of the world. It seems that the reality of global organization into nations, regions, power blocs and political economies are hard for students to grasp. Frequently, anything that is global or international or transnational erases the nationality of the United States as the normalized watchtower from which people look outside to understand the global. The nationality of the Other becomes confusing with terms such as Middle Eastern and Asian. There is frequently productive confusion between notions of global north and south, or western and nonwestern in classrooms. An overview (if a detailed discussion is not possible) of the history of nations and states being studied, how they came into nationhood, how they exercise their statehood, what their relationship is to contemporary global conflicts, and, in case of nations other than the United States, what connections and interdependencies they have with the United States - seems to provide the essential context of studying gender issues.

More than two-thirds of the syllabi for women's studies courses that have the words global and transnational represent non-US issues as global or international. This notion of the distant problemridden global space not here but elsewhere erases the United States' position within global systems and presents various regions and continents (Africa or Latin America) as conflicted spaces existing in historical or political vacuum, their internal affairs (often social injustices) presenting fascinating subjects of study, their citizens objectified as oppressed, and their international relations ignored. Historically constituted subjects transform within textbooks and classrooms into victims and terrorists.

I use map-pointing exercises on the first day of any course that has a large global component. I assign Native American literature in a course on contemporary international literature with a focus on 
gender and sexuality. Students expect Nawal El Saadawi; they do not expect Jeanette Winterson. Their expectations are shaped by where they think "the global" is located, and I try to get to the bottom of such expectations.

\section{Intersectionality}

Only 21 out of 50 syllabi reference the notion of intersectionality in some way, and only two contain a reading (or more) on intersectionality. Any course on diversity or global issues, especially those that focus on gender, race, and class need to begin with a discussion on intersectionality, which is a research and advocacy approach that acknowledges that "the events and conditions of social and political life and the self can seldom be understood as shaped by one factor. They are generally shaped by many factors in diverse and mutually influencing ways. When it comes to social inequality, people's lives and the organization of power in a given society are better understood as being shaped not by a single axis of social division, be it race or gender or class, but by many axes that work together and influence each other" (Collins \& Bilge, 2016, p. 193). Identities are fragmented and simultaneously intensified by globalization yet represented and portrayed simplistically by US academia and popular culture-we cannot let this trend continue in our classrooms. My students learn about intersectionality pretty early and express what they think intersectionality is by drawing it - as a model, a picture, an abstract art, as Venn diagrams. They apply this concept in their discussion and writing. By the end of the semester they are fully aware that identities, communities, and experiences are composite - and that privilege and oppression can be compounded. Many students arrive with a commonsensical idea on intersectionality, but learning about the term and its feminist history helps them advance their thinking.

\section{Debunking the myth of the "first world" as an oppression-free zone}

We need to emphasize experiences of racialization, disenfranchisement, and roadblocks to political and sexual citizenship of various minority groups within first world spaces such as the United States. Otherwise, we create an illusion that all is well here and we need not bother with local activism or politics, or that the world needs to learn from and be protected by the United States in matters of social justice and human rights. The classroom is a space of formulating citizenship practices, resistances, and complicities. The "we are all right" feel-good experienced by many students in the face of learning about human rights abuses "elsewhere" quietly manufactures support for US imperialism in the guise of humanitarianism and rescue. To point out the universality of rape culture and hypersexualization of women is often eye-opening, revealing how controlling images and discourses are shaped by popular culture like that purveyed by Hollywood, Bollywood, and Nollywood alike. (Why movie industries anywhere must be denoted with -wood unleashes interesting conversations about cultural imperialism.)

\section{What about the inter in international?}

Recognition of reciprocity and exchange (often unequal) is important when we study globalization. Analysis of globalization in the class - while mindful of the deepened pace and scale of globalization in the last five decades - should map globalization historically. Students must be reminded of colonization and slavery, trade routes, and traveling historians. Teaching globalization must take into account the exchange of local meanings and experience vis-à-vis the global, the immediacy of the accelerated back and forth nature of discourse generation and the real and symbolic conditions of 
technological and epistemological production. The embeddedness of the students and the instructor in broader processes of capitalism and global systems must be tied to our local, everyday experiences of commodity and cultural consumption and reproduction. The problematic hierarchy of nations, regions, and languages must be brought to question. In all practicality, reciprocal exchange needs an overhaul of the logic of the market and world systems that brings international and transnational publications into the United States as teaching and research materials, as pedagogical and epistemological sources. The trend of US authors telling us about the United States and the world and about the in-between transnational spaces must be disrupted. The market is flooded every year with more and more textbooks on the same topic and field-yet there is little diversity of ideas, approaches, and information, and little or no use of non-US textbooks to study non-US issues. My syllabi analysis also testifies to this trend.

However, the field gender, women's, and sexuality studies is expanding and changing gradually. Previously, the study of gender or women in global or cross-national or multicultural contexts focused specifically on the third-world woman. Mohanty (2003, p. 42) explains this focus as follows:

\section{[A] comparison between Western feminist self-presentation and Western feminist re-presentation of women in the third world yields significant results. Universal images of "the third world woman" (the veiled woman, chaste virgin, etc.), images constructed from adding the "third world difference" to "sexual difference" are predicated upon (and hence obviously bring into sharper focus) assumptions about Western women as secular, liberated, and having control over their own lives. This is not to suggest that Western women are secular, liberated and have control over their own lives. I am referring to a discursive self-presentation, not necessarily to material reality.}

Currently, there is increasing focus on intersectionality, comparative methodology and unpacking the notions of gender, feminist movements, traditions, and culture within women's and gender studies scholarship and within sociology. We need to transfer this criticality back into our classrooms. Considering the volume of students who take women's studies and sociology courses at the undergraduate level by choice and due to institutional (general education or diversity) imperatives, how the "global" or "transnational" is being represented in classrooms, especially at the point of first contact has far reaching implications.

\section{The "so-what" of learning about others}

My final strategy: Such questions from undergraduate students as "Why is this important for me to learn?" "Why do/don't those people think/know/do something?" "Why is the third world so corrupt/poor/unjust?" "How can I help?" "Why is diversity important?" should be dealt with compassion and not condescension. As mentioned earlier, only 19 of the 50 syllabi studied explain why it is important to learn about globalization or different identities and experiences. Despite Audre Lorde's (2007) justified exasperation about educating the dominant or majority group about the minorities' differences, such education must go on. Extreme politico-ideological polarization as is currently common breeds fear, ignorance, and intolerance. Ignorance strengthens the state and other entities stripping citizens of their rights and resources. Only education can counter ignorance, and the role of creative, radical, integrative pedagogy is rather important. For courses on global issues that must be 
taught over the limited timeline of a semester, instructors often have to work harder to provide contexts-historical, economic, and intellectual.

If students have partial knowledge from other classes they have taken on history and geography and anthropology, about the Other or the "outside," these must be drawn on and connected to lessons on global gender relations. The Other and Self must be connected factually and logically, the dialectics of "inside" and "outside" clarified. Jespersen (2014) discusses a form of transformative feminist pedagogy in literature classrooms as "displacement of the self in an effort to understand the places of others" (p. 227). This form of displacement and decentering can occur in any classroom, and create a fruitful environment of understanding global complexity that must be a precursor to discussing social justice and intervention.

Using a transnational feminist pedagogical framework in learning about globalization can be useful to counter the culture of otherization. I have seen this actualize in my own courses where majority of my students begin to think critically about globalization and the numerous invisible ways that their lives - our lives - are connected with others in a global late capitalist world. Before long, they start bringing up examples in the media including their college media about irresponsible representation of peoples and culture, and misrepresentation of diversity. They start thinking critically about their own consumption, their complicity, their responsibility. Of course, in the classroom, we discuss this as "our complicity and our responsibility." We cannot escape our participation in globalization, is there anything at all we can control about our participation?

I ensure that my students know that no discussion on current forms and effects of globalization can leave out stories of globalization centuries back that sailed expedition ships, allowed capitalism to spread and rule like a state and trafficked human beings on whose backs the new worlds got wealthy. One cannot leave out stories of spread of religion and technology, texts, and taxes. One cannot simply start from the present day, when previously colonized, economically drained, arbitrarily created "thirdworld countries" swimming in debt are forced to "open themselves" to capitalism and free trade, which makes their existing inequities deeper and more permanent. Sometimes stories of globalization and geopolitics are too long to teach within a semester-long three-credit-hour course. Perhaps we need to rethink duration and ordering of courses to ensure true learning and unlearning. Most of my students display a trajectory of progressively applying critical thinking in their understanding of the world. They want to know more, learn more. They often take the initiative to learn more by themselves, and long after our class is over, they will email me to share new knowledge, "aha" moments, and accounts of something they did to educate others. Some take independent studies courses with me in which we go in depth on a particular issue, always ensuring that we do not leave out stories and case studies of Others and oppression that occurs within US borders.

\section{CONCLUSION: COMPLICATING IDENTITIES, IDENTIFYING COMPLEXITY}

Universities are internationalizing, and this goes hand in hand with its promotion of neo-liberal free-market orthodoxies. Internationalization is a buzzword in fields as diverse as business education, global heath, women's and gender studies, and other interdisciplinary studies including those within the science, technology, engineering, and mathematics fields. I believe that fields such as gender studies and sociology have an important role to promote critical pedagogy. Monzó (2014) states, "Although the university has always served to solidify state interests, it could be said that this has been done covertly 
with an attempt to maintain the university image as a bastion of free thought and creativity, secured through a presumed objective tenure process that is said to guarantee academic freedom. Currently, we are seeing less concern with maintaining this image as the competition game becomes more vigorous under neoliberalism, often at the expense of programs and courses of study that support the development of critical social understandings" (p. 74). Classrooms are sites of training not just for a career but for consumption and citizenship in an increasingly globalizing world. Teaching globalization without history would be akin to teaching coordinate geometry without providing knowledge of plane geometry and algebra.

Globalization is a condition of growth for US academia- a phenomenon presented as steeped in personal and professional potential, as well as risks - and this trend is unlikely to be reversed. Globalization is as such shrouded in optimism on institutional documents ranging from university mission statements, study abroad curricula, and program webpages (global business education being a prime example) — and taught as a saga of third world catastrophes if syllabi on record are any indication. Teaching interdisciplinary courses that address the complexity of globalization often seems contradictory to the overall university mission of creating global citizens, workers, and consumers. Yet this is the very complexity we need to embrace as instructors, for we need to make our students aware of the world they are inheriting - a world that is inside their homes and neighborhoods, and classrooms, not halfway across the globe. Creating a culture of critical thinking and tracing histories in classrooms prepare my students - most students - to be critical of the United States' status as political watchdog, legitimizer, and neutral, benevolent knowledge maker. We must refashion our classrooms as powerful sites of correcting institutional missions of omissions - teaching students that raising questions is as important as looking for answers. The questions they raise can help us rethink our pedagogy, our research, and our role as university faculty in these interesting political times.

\section{ACKNOWLEDGMENTS}

I thank the anonymous peer reviewers for their interest, insights, and investment. This is a much better article because of reviewer and editorial comments from TLI. Deep gratitude to my students at Utah Valley University, Grand Valley State University, and University of Utah for many critical and productive interactions. Students are the ultimate inspiration for developing my pedagogy and my scholarship on teaching and learning.

Debjani Chakravarty is an associate professor of Sociology and Gender Studies at Utah Valley University (USA) and an area editor for TRAlLS (Teaching Resources and Innovations Library) hosted by American Sociological Association. Her research interests encompass feminist pedagogy and epistemology, sexualities, globalization, and new media.

\section{REFERENCES}

Alexander, M. J., \& Mohanty, C. T. (2010). Cartographies of knowledge and power: Transnational feminism as radical praxis. In A. Swarr \& R. Nagar (Eds.), Critical transnational feminist praxis (pp. 23-45). Albany, NY: State University of New York Press.

Ang, I. (1995). I'm a feminist but ... "Other" women and postnational feminism. In B. Caine \& R. Pringle (Eds.), Transitions: New Australian feminisms (pp. 57-73). New York, NY: St. Martin's Press.

Chaput, C. (2008). Inside the teaching machine: Rhetoric and the globalization of the US public research university. Tuscaloosa, AL: University of Alabama Press. 
Chowdhury, E. H. (2009). Locating global feminisms elsewhere: Braiding US women of color and transnational feminisms. Cultural Dynamics, 21(1), 51-78. https://doi.org/10.1177/0921374008100407

Chowdhury, E. H. (2011). Transnationalism reversed: Women organizing against gendered violence in Bangladesh. Albany, NY: State University of New York Press.

Collins, P. H. (1986). Learning from the outsider within: The sociological significance of black feminist thought. Social Problems, 33(6), S14-S32. https://doi.org/10.2307/800672

Collins, P. H., \& Bilge, S. (2016). Intersectionality. Cambridge: Polity Press.

Darla Moore School of Business (n.d.) International requirement. University of South Carolina Retrieved from https://sc.edu/study/colleges schools/moore/study/programs and degrees/undergraduate programs lundergraduate curriculum/international requirement/

Desai, J., Bouchard D., \& Detourney D. (2010). Disavowed legacies and honorable thievery: The work of the "transnational" in feminist and LGBTQ studies." In A. Swarr \& R. Nagar (Eds.), Critical transnational feminist praxis (pp. 23-45). Albany, NY: State University of New York Press.

Doerr, N. M. (2016). Chronotopes of study abroad: The cultural Other, immersion, and compartmentalized spacetime. Journal of Cultural Geography, 33(1), 80-99. https://doi.org/10.1080/08873631.2015.1065030

Downing, D. B. (2014). What does neoliberalism have to do with teaching research writing? Radical Teacher, 100(Fall), 126-132. https://doi.org/10.5195/rt.2014.168

Felten, P. (2013) Principles of good practice in SoTL. Teaching \& Learning Inquiry, 1(1), 121-125. https://doi.org/10.20343/teachlearninqu.1.1.121

Freire, P. (2005). Pedagogy of the oppressed (M. B. Ramos, Trans.). New York, NY: Continuum.

Grewal, I. (2005). Transnational America: Feminisms, diasporas, neoliberalisms. Durham, NC: Duke University Press.

Hobart, M. (2002). Introduction: The growth of ignorance? In M. Hobart (Ed.), An anthropological critique of development: The growth of ignorance (pp. 1-30). New York, NY: Taylor and Francis.

Jespersen, T. C. (2014). Literary identification as transformative feminist pedagogy. Feminist Teacher, 24(3), 221 228.

Kaplan, C. (1994). The politics of location as transnational feminist critical practice." In I. Grewal \& C. Kaplan (Eds.), Scattered hegemonies: Postmodernity and transnational feminist practices (pp. 137-152). Minneapolis, MN: University of Minnesota Press.

Lea, Y. (2006). The matrix of Freirean pedagogy: Time and cultural literacies. In C. A. Rossatto, R. L. Allen, \& M. Pruyn (Eds.), Reinventing critical pedagogy (pp. 207-224). Lanham, MD: Rowman \& Littlefield.

Lorde, A. (2007). Sister outsider: Essays and speeches. Berkeley, CA: Crossing Press.

McLaren, P. (2006). Some reflections on critical pedagogy in the age of global empire. In C. A. Rossatto, R. L. Allen, \& M. Pruyn (Eds.), Reinventing critical pedagogy (pp. 79-98). Lanham, MD: Rowman \& Littlefield.

Mies, M., \& Bennholdt-Thomsen, V. (1999). The Subsistence perspective: Beyond the globalised economy (M. Mies \& P. Camiller, Trans). London: Zed Books.

Minh-Ha T. T. (1989). Woman, native, other: Writing postcoloniality and feminism. Bloomington, IN: Indiana University Press.

Moallem, M. (2006). Review: Feminist scholarship and the internationalization of women's studies. Feminist Studies, 32(2), 332-351. https://www.jstor.org/stable/20459089

Mohanty, C. T. (1988). Under Western eyes: Feminist scholarship and colonial discourses. Feminist Review, 30(Autumn), 61-88. https://www.jstor.org/stable/1395054

Mohanty, C. T. (2003). Feminism without borders: Decolonizing theory, practicing solidarity. Durham, NC: Duke University Press.

Monzó, L. D. (2014). A critical pedagogy for democracy: Confronting higher education's neoliberal agenda with a critical Latina feminist episteme. Journal for Critical Education Policy Studies, 12(1), 73-100. Retrieved from http://www.jceps.com/wp-content/uploads/PDFs/12-1-03.pdf

Ong, A. (2006). Neoliberalism as exception: Mutations in citizenship and sovereignty. Durham, NC: Duke University Press.

Office of Undergraduate Studies, University of Utah (2019). International (IR) criteria mission statement. Retrieved from https://ugs.utah.edu/general-education/requirements/ir.php\# 
Pfeil, F. (1994). No basta teorizar: In-difference to solidarity in contemporary fiction, theory, and practice. In I. Grewal \& C. Kaplan (Eds.), Scattered hegemonies: Postmodernity and transnational feminist practices (pp. 197-230). Minneapolis, MN: University of Minnesota Press.

Spivak, G. C. (1988). Can the subaltern speak? In C. Nelson and L. Grossberg (Eds.), Marxism and the interpretation of culture (pp. 271-313). Basingstoke: Macmillan.

van Djik, T. A. (1993). Principles of critical discourse analysis. Discourse and Society, 4(2), 249-283. https://doi.org/10.1177/0957926593004002006

\footnotetext{
(c) (1)

Copyright for the content of articles published in Teaching \& Learning Inquiry resides with the authors, and copyright for the publication layout resides with the journal. These copyright holders have agreed that this article should be available on open access under a Creative Commons Attribution License 4.0 International (https://creativecommons.org/licenses/by/4.0). The only constraint on reproduction and distribution, and the only role for copyright in this domain, should be to give authors control over the integrity of their work and the right to be properly acknowledged and cited, and to cite Teaching \& Learning Inquiry as the original place of publication. Readers are free to share these materials — as long as appropriate credit is given, a link to the license is provided, and any changes are indicated.
} 